\title{
CHAPTER 5: FROM VALUE PROTECTION TO VALUE PROMOTION: INTERPRETING BRITISH SECURITY POLICY
}

\author{
Oliver Daddow and Jamie Gaskarth
}

Security policy lends itself to interpretivist analysis as security is an 'essentially contested concept' (Buzan 1991: 7-11). This is because neither security theorists nor practitioners can agree on the referent object of security, what actions would render something secure, and what that security might look like. At times, the referent object is ideological (liberty, equality, religious purity), or institutional (democracy, the rule of law, sovereignty, the state), but it can also be material (stability of borders, physical safety of individuals, group integrity). Sometimes bringing about security might require change; whilst at other times, change itself is presented as threatening to the security of the existing order. Security practitioners continually have to interpret the world around them, deciding what needs to be secured, what might threaten the referent object's security, and how these threats might be addressed.

Since 1945, British policymakers have been compelled to deal with the ramifications of this fluid interpretation of security. In one lifetime, Britain has declined from being an Imperial power with global interests to the island of Great Britain, Northern Ireland and fourteen small overseas territories. In managing this decline, policymakers had to redefine what 'essence' of Britain the nation's security policy was trying to preserve as its material make-up underwent major change. As a result, questions of identity have never been far from the surface. Debates about what core elements of 'Britain' needed to be secured were bound up with arguments over which elements of British identity need to be defended. A number of excellent studies have analysed how Britain has forged its domestic security policy (Bonner 2007; Donohue 2008; Hewitt 2007). This chapter argues 
that the manner in which British elites have positioned Britain in the wider world tells us a great deal about how they have come to perceive its global identity, and what aspects of this it values and wishes to secure. For reasons of space we concentrate on the most influential and readily accessible sources of thinking about Britishness - elite opinion whilst acknowledging that they are reflected by and within wider cultural currents of opinion, for example in the media, the academy, and civil society at large.

To achieve this goal, we start from the assumption that policymakers interpret and make sense of security policy in relation to inherited traditions that shape decision-making. Some of these traditions have proved pervasive. Such themes as continuity and bipartisanship have long been prominent and arguably militated against radical reconsideration of Britain's position in world affairs (Gaskarth 2006). Despite such structural upheavals as world wars, the end of Empire and the end of the Cold War, British foreign, defence and security policies are seen as remarkably impervious to change over time (Kennedy 1985; Clarke 1988; Theakston 2004). In foreign policy 'marginal rather than decisive' breaks have been the order of the day (Vickers 2011: 127) and 'disagreement on foreign policy has tended to be on emphasis, timing and detail, and has not extended to the main principles' (Shlaim 1977: 26). Lacking much in the way of ideological fervour, the British have usually fallen back on their supposedly unique qualities such as practicality and pragmatism to define the national 'style' of managing foreign policy (Hurd 1998; Coles 2000). 'If it ain't broke don't fix it', the saying goes, and this has held for British decision-making on foreign policy with the pragmatists ‘usually’ proved right (Meyer 2010: 200).

Yet, we argue, material changes in Britain's relative global power have compelled policymakers to reinterpret and alter important aspects of British identity and culture. 
Ideas of racial superiority, Christian proselytising, and 'splendid isolation' have been marginalised. Pluralism, multiculturalism and interdependence are now privileged, although the idea of the British 'island race' retains rhetorical purchase on the libertarian right, particularly on the vexed question of European integration (well covered in Brown 2013).

Interpretivism deals with constructions, but - and here we echo John Searle (1995) - the acceptance of a constructivist sensibility does not necessarily entail the suggestion that the world is only an ideational construct for the agents involved. Nor does it see the production of meaning as structurally determined by contextual forces. Rather, interpretivism explores how individual agents interact with the social and the material worlds, in the process illuminating the traditions which shape the beliefs and practices of policymakers and are shaped by them. These traditions are often leaned upon and reinterpreted in response to policy dilemmas. Challenges to prevailing social, political or economic assumptions occur regularly in the dynamic environment of international politics. As policymakers grapple to understand and respond to these developments, they often make overt references to traditions as a way of endowing their actions with meaning and rendering them intelligible and legitimate in the eyes of others.

In this chapter, we explore one particularly important tradition of British external policymaking: the desire to maintain Britain's great power status. This has arguably shaped all aspects of Britain's strategic security policy thinking and national security practices from the Second World War to the present. The prolonged build-up to European Economic Community (EEC) entry in 1973 and the aftermath of the Cold War represent two distinct periods within which we identify dilemmas being recognised, interpreted and acted upon by British decision-makers. The first section brings into dialogue the 
literatures on British foreign policy and security culture as a way of illustrating what is often taken to be a remarkably persistent tradition of thought about Britain in the world going back to Winston Churchill in 1948. In the second section we explain how we have set about using this book's analytical framework of traditions and dilemmas by surveying a previous dilemma for the British political establishment - the recognition that Britain was no longer a globally dominant actor which grew to prominence over the period of the Suez crisis in 1956 to defence retrenchment from east of Suez in 1967. The third section considers how Britain coped when existential security threats - such a potent force in identity creation and reinforcement - no longer pertained after the Cold War. We examine the beliefs on which policy-makers drew to inform their appreciation of the meaning for British security of the collapse of the Soviet threat, and try to gauge how those beliefs altered in response to new knowledge about the global security environment as it emerged and was processed through an engagement with changing security thinking and practice after 1989.

We argue through the chapter that the years after 1989 witnessed British decision-makers facing a radical dilemma over security policy, a much more radical one than the earlier reorientation to an Europeanist approach in the 1970s. How could security be defined and guaranteed when the Soviet threat to the integrity of the state had collapsed and 'new' or what came to be known as 'asymmetric' threats (see King 2008: 649) were neither as visible nor as manageable using armed force as during the supposed heyday of Cold War and Empire? Defence reviews over this period have reinforced the impression that Britain no longer faces physical threats to its security but is confronted by a series of diffuse challenges that are not national but global. National elites have, more by luck than judgement, been able to reinvigorate the decades old Churchillian idea that Britain can enact a 'great' global role, but they have constantly had to recalibrate how to achieve this 
elusive goal. In particular, accepting that global interdependence has compelled a redefinition of the national interest, politicians have switched from security conceived as the protection of territory and liberal values, to security as the promotion of liberal ethics and, where necessary, expeditionary intervention into other states' territories. 'Making the world safe for democracy' has become coterminous with 'making the world safe for Britain'. In short, since the end of the Cold War Britain's tactics might have altered, but the overall strategy of maintaining a global leadership role remains undimmed. Core remnants of the 'great power' tradition have thus been reshaped to account for the promotion of values alongside the protection of interests.

\title{
INTERPRETING SECURITY TRADITIONS: FROM FOREIGN POLICY TO STRATEGIC CULTURE
}

\begin{abstract}
The structure and patterns can only be discerned by standing back from the immediate battles with a long-term rather than a short-term perspective, examining those things that the participants take for granted: the shared images, assumptions and beliefs and the "rules of the game" (Freedman 1976: 449).
\end{abstract}

At first sight British security policy might not seem to offer much in the way of fertile ground for an interpretivist approach. Conceptions of Britain's role in the world have, the consensus goes, been relatively impervious to change over time, with the hazy notion of playing the part of a 'global power' producing little in the way of explicit discussion of the purpose of foreign policy. Writing in 2000, former Permanent Under Secretary (PUS) at the Foreign and Commonwealth Office, John Coles, noted that the last Prime Minister to attempt to explain Britain's long term strategic objectives was Winston Churchill with 
his 'three circles' model in 1948. Churchill argued that Britain occupied a unique position in global affairs because it was positioned at the epicentre of the 'three great circles among the free nations and democracies': the British Commonwealth and Empire, the 'English-speaking world', particularly the US, Canada and Australia, and, very much last on the list, 'United Europe' (Churchill 1948: 153). Since Churchill's time, Coles contends (2000: 4), not much has altered because 'there has been a failure or an inability to define an overall purpose for Britain overseas'.

Commentators from within the academic community have generally found Coles to be correct, suggesting that if we appreciate Churchill's worldview we can understand the practice of British foreign policy since 1945 (see Deighton 2005; Hill 2010). William Wallace suggests (2004: 424) that Churchill managed to create a 'consensus' about the national interest in 1940 which saw Britain through arguably the most serious challenge to its national security in living memory. His "idealised and inspirational "toughness"” as well as his resoluteness to stand firm against tyranny are regularly invoked by politicians in Britain, the US and, ironically in some cases, by leaders well outside of and opposed to ideas that resonate in the transatlantic policy community such as Saddam Hussein (Toye 2008: 365 and 374). Churchill's view of a peace-loving 'sceptred isle set in a silver sea' powerfully supported by the English-speaking peoples around the globe 'set the context for British foreign policy in the decades after the war' (Wallace 2004: 432). When Churchill's successors have tried to find a form of words to update the three circles model they have fallen on deaf ears.. Either they have been 'largely ignored by the media' (Coles 2000:4), or, we suggest, they have been so heavily indebted to the Churchill model that such novel elements as they contained were subsumed into stilted linguistic rendering around notions of pivots and hubs (Daddow 2011: 222-24; Daddow and Gaskarth 2011). Douglas Hurd's 1992 suggestion that through the 1980s and early 1990s 'Britain has 
punched above her weight in the world' (quoted Wallace 1992: 438) is perhaps the nearest we have to a successor to the Churchill cliché, yet it is getting at the same idea. In other words, regardless of the obvious domestic and international upheavals Britain has encountered in the second half of the twentieth century and beyond, a tradition of thought which sees Britain at the centre of global decisionmaking, with an influential role in the world, has persisted. The imaginative horizons of how Britain can, and should, act in the global arena remain extensive despite the decline in its relative material capabilities.

Furthermore, even though identifying 'national' or broader 'Western', approaches to security is problematic following the onset of the Revolution in Military Affairs and the move to transnational organizational frameworks and networked war (Gautam 2009: 41516), we would argue that it is possible to discern national strategic cultures linked to underlying foreign policy traditions. The traditions are significant because policy-makers believed them to exist and acted on those beliefs accordingly. For instance, Øivind Bratberg (2011) points out that British foreign policy since 1945 has been driven by five interlocking concerns:

...a privilege for Anglo-American relations, with NATO as corollary; insular reserve towards the European continent; a maintained global presence with special preference for the Commonwealth; a policy based on pragmatism rather than principle; and, finally, a liberal belief in international trade (Bratberg 2011: 331).

Bratberg identifies that the British tradition is founded on both substance (the geostrategic content of the relationships the country has sought to put in place to safeguard its security) and a certain pragmatic style that is essentially reactive and forecloses the need for much in the way of theoretical reflection or what could pejoratively be deemed the 
'intellectualisation' of British foreign policy. Bratberg's 'insular reserve' point is perhaps the emblematic one to take away from what is a standard account of Britain's foreign policy priorities. It is certainly echoed in the literature on strategic culture and national ways of war (defined and surveyed in Uz Zaman 2009) which takes seriously ideas as they affect the practice of the use of force at state and increasingly transnational levels.

We conclude this section by noting, therefore, that the Churchill 'tradition' has been a powerful force in British foreign policy rhetoric since 1945. Alastair Miskimmon argues (2004) that Churchill's ordering of the three circles, with Europe at the bottom, even holds for periods, such as post-1997, when supposedly Europeanist Prime Ministers have been resident in Downing Street. Even under Tony Blair, he suggests, Britain remained torn between engaging wholeheartedly in European initiatives which may lead to tighter political integration and enacting an Atlanticist vision of pre-emptive security which came to a head with the Iraq invasion of 2003. In a similar vein, Sten Rynning suggests (2003) that the EU's persistent inability to undertake a coherent supranationally managed defence policy has suited the British (as well as French and German policy-makers), in part because it defers the question of duplication with NATO structures and in part because it frees the bigger European powers to involve themselves in flexible coalitions of the willing to deal with security threats. Whilst the strategic environment may have altered quite dramatically since Churchill's time, it would appear that British policy-makers have been able to proceed relatively untroubled through choppy waters by falling back on their tried and trusted pragmatism. The extant literature certainly implies a straight line can be drawn from Churchill to the present, whether this be articulations of foreign policy 'vision' (such as they are) or the practical expression of ideas in security practices, which continue to privilege the Atlanticist over European or other possible ideational inspirations for action. 


\section{POST-WAR DILEMMAS}

We argue that using the framework of traditions and dilemmas helps us appreciate that such apparent 'givens' in Britain's global outlook have not been given for all time. Two examples illustrate why this is significant. First, the 'special relationship' is a historically contingent and still emerging entity, not the natural 'order of things' because 'relations between Britain and the United States during the 150 years before 1940 were marked by suspicion and rivalry as much as mutual understanding' (Wallace 1992: 440). The reputation it has been accorded is not necessarily in line with what is a contested historical record, either before Churchill's time or, in fact, during it, with a succession of US Presidents evidently rather bored by the Prime Minister's constant references to it (Toye 2008: 367).

Second, Margaret Thatcher cited Churchill as a visionary of European integration in the run-up to the 1984 European Parliament elections. Given her now iconic status as a staunch critic of European integration and the renowned apathy about European integration on the part of the British public we might have expected Thatcher to have ignored Churchill's zeal for a united Europe in favour of a more pragmatic line that accepted his view that Britain's European relations were, at best, a necessary evil in the pursuit of British interests. That she went so far to rebalance the historical memory of Churchill shows the power of circumstances at the time and the 'multiple uses' to which Churchill's memory can be put (Toye 2008: 370). There is nothing inbuilt into the structure of the Churchill 'consensus' that determines the composite beliefs of agents facing electoral or other pressing political pressures. The interpretivist perspective allows us to dig down into the lifeworld of the individual agent as they form their beliefs in a 
wider collective dialogue with the past and the present; it reminds us that the history of the reception and popularisation of a narrative tradition is never quite as simple as it may appear in hindsight when it becomes sedimented as a collective social and institutional 'fact' (Searle 1995: 113-126).

We agree therefore that foreign and security policy thought has remained heavily dependent on Churchillian imagery and rhetoric, but suggest that the beliefs that sustain this tradition have not been fixed. In fact, the tradition itself has undergone some subtle but perceptible and important shifts over time. In foreign policy we would not expect dilemmas, however acute, to prompt overnight alterations to thinking or practice, yet over tectonic shifts are detectable beneath the surface. We illustrate how we can track these medium- and long-term alterations to foreign and security policy beliefs using the period from 1945-73 as a case study in geostrategic upheaval creating a series of dilemmas which were only slowly and reluctantly recognised as dilemmas by elite decision-makers.

Ultimately, they came to appreciate that Britain faced an existential crisis of national identity. Decolonisation and relative economic decline meant that global troop deployments - the embodiment of Britain's national identity as a world power - were unsustainable. As policies altered in response to this new knowledge, the web of beliefs that sustained the Churchillian tradition had to be reconfigured.

Table 1: Dilemmas in British foreign and security policy, 1945-73

\begin{tabular}{|l|l|l|l|}
\hline Pre-1973 & Web of beliefs & Dilemmas & Post-1973 \\
tradition & & & tradition \\
\hline
\end{tabular}




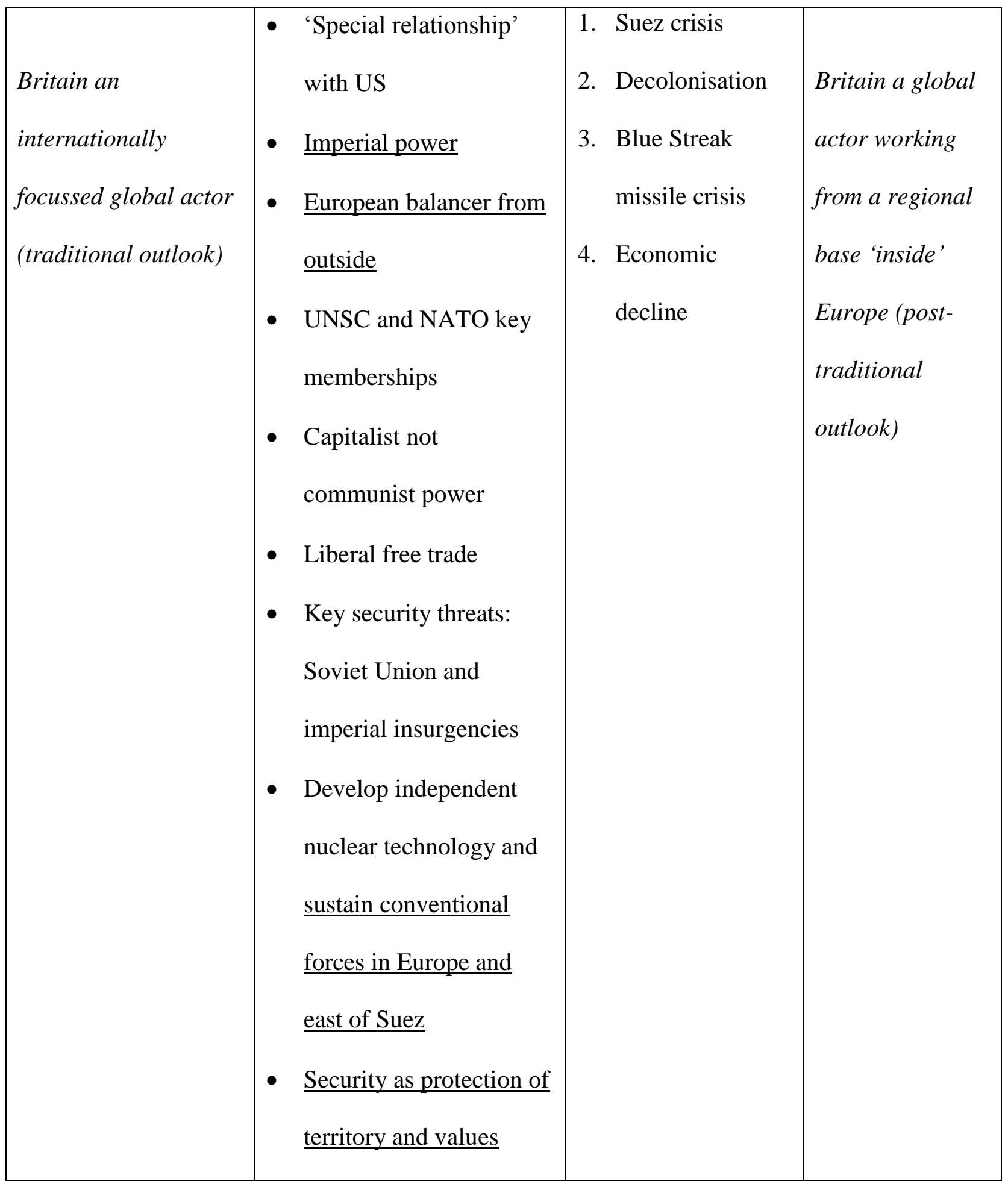

NB, Underlined beliefs are those that were reconfigured as decision-makers began to realise the scale of the foreign and security dilemmas they faced (see below). 
Table 1 illustrates how we have enacted the traditions and dilemmas framework for understanding the interaction between beliefs and traditions in British foreign and security policy at a time of upheaval in the international system. In the left column we identify the pre-1973 tradition of thought about Britain's identity, role in the world and the concomitant foreign and security posture which was encapsulated by Churchill and widely accepted by politicians across the political spectrum. This was the vision of Britain operating at the intersection of its three circles of power and influence to shape global developments. It fed through into, for instance, Harold Macmillan's conviction that Britain could play Greece to America's Rome by helping Washington learn how to execute responsibly its new found global great power status, and simultaneously turn that power in Machiavellian fashion to serve British interests. Flawed though it was, according to Nigel Ashton, the Greek-Roman rendering of the 'special relationship' lasted well into Macmillan's time as prime minister, 1957-63 (Ashton: 697-698). In the other circles, the Commonwealth provided Britain with diplomatic connections and economic resources, and London looked to encourage European integration but very much from the outside.

In the second column above we identify the web of beliefs that sustained the Churchiallian tradition. This is the tradition that informed the British establishment's interpretation of Britain as a global actor in the early post-war years. The first three beliefs were those associated with Britain's geopolitical position. First, the newly discovered wartime 'special relationship' with the US was built on the shared history of recent military endeavour against the Axis powers, intelligence sharing, cultural connections and common language. Second, the Commonwealth was important because it was 'considered to be the source of [Britain's] structural power at the time' (Váška 2009: 121).

Continental Europe remained the most problematic of the three circles and certainly in the first fifteen years after 1945 British policymakers could not quite let go of the idea that 
Britain should act as a balancer outside rather than inside Europe. London stood aloof from the creation of the European Coal and Steel Community (ECSC) in 1950-52, the European Defence Community (EDC) in 1950-54, of which Churchill was extremely critical, and then the Rome Treaty that led to the establishment of the EEC in 1957.

The remaining beliefs that informed and were informed by this tradition flowed from how British policymakers viewed Britain's identity as a global actor in these circles of influence, and how they constructed global developments in the emerging Cold War as threats to British security and interests. Fourth, then, alliance building in NATO led by its trusted partner of choice, the US, trumped anything the Europeans might have hoped to build in the form of the EDC. A seat at the UN P-5 table reinforced Britain's selfperception as a great global power. Fifth and sixthly, policymakers saw Britain's identity firmly within the 'Western' camp as a capitalist power pursuing liberal free trade abroad combined with nationalisation of key industries such as the coal and steel at home, particularly under the reforming Clement Attlee governments of 1945-51. They were combined uneasily with elements of an imperial posture in short-lived Franco-British designs in 1946-48 to recolonise parts of the Belgian Congo to build a European 'Third Force' distinct from both Soviet style Communism and US style capitalism (Kent and Young 1989). Thus, policies inspired by the 'socialist' tradition could be said to have been one of the mitigating factors against Britain's closer entanglement in what was seen as a Christian Democratic and capitalist continental Europe in the early years of the integration project. Meanwhile, collaborative ventures as the doomed Third Force seemed to teach London elites that its European neighbours would not provide Britain with the requisite stability or resources to pursue its security interests in the emerging Cold War, hence the much-vaunted turn to NATO in 1949. 
Seventh, the core security challenge facing Britain was no longer from Germany (although it was not ruled out, even in its divided and externally managed state) but from the Soviet Union. In addition to fears about the Soviet threat to UK territory, colonial insurgencies such as in Malaya kept London's focus on the global picture and in a state of tension about Communist incursions into 'Western-friendly' territories. Combining great power pretensions with basic security concerns there was, eighthly, a belief that Britain should develop the 'ultimate' deterrent of nuclear weapons, and that its 'bomb' should be independent of US input. Research and development that began under the Attlee Labour governments continued unabated through the Conservative years 1951-55 when Churchill was back in power (see Mawdsley 2013, in this collection). This was a source of broad but not total cross-party agreement from the leaderships. For example, the 'Keep Left' wing of the Labour Party questioned the ethics of nuclear weapons research and testing and was suspicious of what it saw as Britain's slavish adherence to US security practices. The final belief is a touch harder to pin down but it can be summarised as the assumption that security at this time was about national survival and the protection of national interests. This belief consisted of a 'hard' security agenda emphasising the protection of national territory, colonial territories and the territorial integrity of liberal democratic states against a potentially revanchist Germany and/or Communist Soviet Union.

The web of beliefs that sustained this traditional approach to British foreign and security policy sat in a dynamic relationship with each other, so that as new knowledge came to light that caused individuals to reconsider their faith in one belief, so other beliefs became destabilized and subject to reassessment. The underlined beliefs in Table 1 are those that changed, as policymakers perceived that the Churchillian conception of British foreign and security policy was no longer sustainable in the first two decades after the Second World War. 
Four dilemmas were most apparent in bringing about this reassessment. First, the Suez crisis of 1956 taught British leaders the lesson that it was dangerous to act contrary to the wishes, and/or without the support of, the Washington government. It further damaged relations with France after the failure of the Third Force, and was widely vilified as the desperate actions of a colonial power in decline. Suez therefore bolstered the US circle, disrupted Britain's leadership of the Commonwealth circle and left the Europe circle as indecipherable to London as before. The second dilemma came from decolonisation. The Suez affair confirmed in the Commonwealth circle that Britain could no longer exert the global leadership it once did as countries formerly administered by the Empire called for independence to make their own way in the world. This process began with India and Pakistan in 1947 and the pace rapidly picked up in the 1960s as the 'winds of change' blew through the British territories in Africa.

The third dilemma struck at the heart of Britain's security concerns and great power pretensions - the Skybolt missile crisis leading to the Nassau Agreement of December 1960-62. The John F. Kennedy administration's planned cancellation of the Skybolt missile system announced in late 1962 would have singlehandedly destroyed the opportunity for a UK nuclear deterrent in the 1960s. The Nassau Agreement Kennedy negotiated with Prime Minister Macmillan enabled Britain to buy the replacement Polaris system for use with British warheads. Nassau showed that the British were fundamentally reliant on the US for the ultimate security guarantee; that the defence of Europe against a conventional or Soviet threat needed more in the way of a British and/or European effort in case the US could not or chose not to be involved in a hot war; and it emphasised the fragility of the economic basis on which Britain's great power pretensions were being maintained. 
This links to the final dilemma which was new knowledge about Britain's ailing economy and changing trade patterns away from the Commonwealth and towards Europe, both of which impinged on the relative balance London elites accorded the three circles in their foreign and security policy thinking. The British economy suffered low rates of growth compared to its European counterparts in the first three decades after the Second World War; its share of global markets plummeted from $25 \%$ in 1950 such that by 2000 it was just 5\% (Váška 2009: 123). It was only when the Treasury took a firm and what became a 'critical' grip through the Lee Report of 1961, however, that the message started to hit home to Macmillan and his Cabinet (Toomey 2003: 229) that Europe might be a solution. It was underscored by the discovery that the Commonwealth had been replaced at the beginning of the 1960s by the EEC as Britain's main trading partner (Váška 2009: 123).

Together, this series of dilemmas added up to a period within which new knowledge about Britain's reduced standing in the world as the country at large prompted decisionmaking elites to fear for the nation's future health, and they added up to one big dilemma: the dilemma of decline. The first application to join the EEC was launched by the Macmillan's Conservative government in 1961-63 on the basis of economic calculations about the British interest, not any sudden conversion to the European ideal. It offered 'a potentially valuable solution to a period of economic and political difficulty' (Kavanagh and Morris 1994: 106). Labour's Harold Wilson launched a second and similarly unsuccessful application in 1967 on the same calculation of costs and benefits to Britain's ability to play out a great power role without getting its economy in order (see Daddow 2003). In particular, the stabilisation loan of $£ 850$ million from the International Monetary Fund loan in 1964-65 could not stave off the devaluation of sterling in November 1967 or the need for a further IMF loan in 1968 (Váška 2009: 126-27). Defence cuts and 
retrenchment to bases east of the Suez Canal exposed as a sham Britain's ability to maintain a global presence because it meant the 'end of Britain's global military role' and confirmed its reduced status compared to the US and Soviet Union. As Toye (2008: 369) notes: 'The [Lyndon] Johnson administration saw this as weakening the fight against communism in South-East Asia, and the State Department determined that it would no longer make favourable comparisons between Wilson and Churchill as it had previously'.

Britain finally joined the EEC under Edward Heath in 1973, marking what Váška (2009) calls the onset of a post-traditional foreign and security policy. It was not 'modern' because memories of the past still haunted policy-makers who had been schooled on Empire and - largely - global military successes, memories which resonate to this day (Daddow 2011; Gaskarth 2013). In this section we discussed the interaction between traditions and beliefs about British foreign and security policy in the period 1945-73, and seen how these altered in response to dilemmas. The next section will use this framework to assess the traditions, beliefs and dilemmas that altered British security thought and practice after the Cold War.

\section{RECONFIGURING THE TRADITION: FROM POST-WAR TO POST-COLD}

\section{WAR}

In the post-Cold war era, a new dilemma for policymakers emerged: how could they plan for Britain's security in the apparent absence of existential threats? When the Soviet Union collapsed, it left the UK operating in a security environment that was less threatening than at any time since perhaps the 1830s. The downfall of communist regimes across the European continent meant that social democracies such as Britain no longer 
had to be wary of internal or external ideological challenges. As Malcolm Chalmers puts it, Europe had 'evolved into a deeply rooted "peace community"' in which war between European states was no longer 'a factor in defence planning' (Chalmers 2011: 25).

So many of the trappings of great power status are bound up with military capability whether possession of an independent nuclear deterrent (Allen 2011; Wallace and Philips 2009: 270), or the capacity to deploy a division-sized force into combat within a matter of months (King 2011) - that an absence of threat might have posed problems for Britain's great power identity. However, in a famous speech to the Conservative party conference in 1995, the then Defence Secretary, Michael Portillo, declared: 'we are not ashamed to celebrate Britain's military prowess...to remind the world that this great nation will not be put upon, before evoking the motto of the SAS, 'Who Dares Wins' as a rallying cry of national purpose (Portillo 1995). Yet the sentiments Portillo evoked were already anachronistic. No other state was trying to 'put upon' the UK in the decade after the Cold War ended. Nor, even eighteen years later, has any state emerged to pose an existential threat to Britain's survival as a territory or political community.

The first serious effort to strategize Britain's defence planning after the Cold War, the 1998 Strategic Defence Review (SDR), began with the declaration that: 'there is today no direct military threat to the United Kingdom or Western Europe. Nor do we foresee the reemergence of such a threat' (MOD, 1998: 8). Although it went on to suggest that instability in Bosnia and Kosovo threatened British security, and instability in Africa might do so indirectly, it did not discuss existential threats to the UK itself, but possible threats to individual citizens or British interests abroad. Such threats were far more diffuse and open to interpretive dispute compared to the overwhelming danger of invasion or, later, nuclear annihilation, that the UK had faced for much of the twentieth century. 
In the aftermath of the Cold War, Britain reduced its forces by a third and its defence budget declined by 23\% in real terms between 1990 and 1998 (MOD 1998: 9). In the absence of existential security threats, and facing recession at home, the UK adopted a circumspect approach to military commitments abroad. When ethnic conflict broke out in the Balkans with the break-up of Yugoslavia, the UK deliberately limited the mandate of UN forces on the ground - of which British forces were a significant part - to avoid becoming embroiled in offensive operations (Kampfner 2003: 37). It also actively resisted efforts to involve the Security Council in the ethnic conflict in Rwanda (Curtis 2004: 281282).

However, the human cost of these policies and the responsibility Britain held for blocking attempts to confront human rights abuses in Bosnia and Rwanda with force meant that Britain's identity as an effective military and political actor was tarnished. When ethnic conflict broke out in Kosovo in 1998, it is possible to see a desire to reaffirm British leadership in the region and thereby reassert Britain's great power status. Tim Garden notes that: 'From the start the UK Government saw itself in a leading role in Europe, in NATO and in the UN', citing Robin Cook's statement to the house that: 'No nation has done more to seek a peaceful settlement for Kosovo than Britain. It was Britain that convened and chaired the Heathrow meeting of the Contact Group ... It was Britain which then made a leading contribution to the verification mission to police the supposed ceasefire. It was Britain and France that jointly chaired the peace talks at Rambouillet and in Paris' (Garden 2000). Cook favourably contrasted the restoration of Britain's identity as a leading power with the previous administration's more cautious approach to the use of force during the Bosnian war: 'Milosevic was beaten in Kosovo. If our predecessors in 
Government had acted as decisively to stop him in the past decade then we would never have seen the tragedy of Kosovo (Cook 1999).

The human rights abuses committed in Kosovo by Serbian forces were on a far smaller scale than those which had occurred in Bosnia. What was arguably different was, in part, the desire to reaffirm British leadership by adopting a more active approach to confronting ethnic conflict. Doing so allowed Britain to express its status as a great power, demonstrated its capacity for military action, and in the process, justified the continuation of high levels of defence spending despite the lack of a significant threat to the mainland. As such, it served a number of political ends. To gain international support for military action in what was a civil conflict, a number of overlapping traditions were evoked. Most prominently, neoliberal beliefs about the globalising character of world politics and the increasing interconnections between communities, both economic and political, contributed to the sense that previous assumptions about sovereignty no longer applied. Westphalian categories of foreign and domestic, inside and outside the state, standing in the way of intervention, were dismissed in favour of a belief that globalisation had made them redundant. Interdependence, it was argued, exaggerated the susceptibility of states to security threats, while global media technologies brought an immediacy and urgency to the pictures and stories of human suffering from far flung parts of the world.

Importantly, this belief about political transformation was directly linked with the tradition of neoliberalism by policymakers. For instance, Tony Blair asserted in his Chicago speech in 1999 that:

Globalisation has transformed our economies and our working practices...We are all internationalists now, whether we like it or not. We cannot refuse to participate 
in global markets if we want to prosper. We cannot ignore new political ideas in other counties if we want to innovate. We cannot turn our backs on conflicts and the violation of human rights within other countries if we want still to be secure (Blair 1999b).

Underpinning this argument was the globalising and universalising tradition of neoliberalism. Neoliberal economics, opening up markets and creating social links across borders were seen as feeding into a process of spreading universal political values. Robin Cook argued the following year that:

the age of globalisation is creating more progressive pressures. Regimes which govern their citizens by fear and repression cannot expect the same people to display the creativity and innovation in the workplace which are essential for a knowledge-based economy (Cook 2000).

The result of this interdependence was, for New Labour policymakers, a pressure to converge around a common set of global beliefs, a 'global alliance for global values, as Blair described it (Blair 2006b).

Importantly for security, this led to a belief that challenges to these values abroad constituted a threat to Britain, via this sense of global interconnectedness. At the regional level, geographical proximity lent weight to the sense of direct British interests under threat. In his statement to the House of Commons on 23 March 1999, Blair argued for action on the basis that: 'If Kosovo was left to the mercy of Serbian repression, there is not merely a risk but a probability of re-igniting unrest in Albania; Macedonia destabilised; almost certain knock-on effects in Bosnia; and further tension between Greece 
and Turkey' (Blair 1999a). Putting Britain in the position of regional spokesman, he asserted that: 'There are strategic interests for the whole of Europe at stake' (Blair 1999a). However, the same processes would, for Blair, also have global ramifications. In a reflective speech towards the end of his Premiership, Blair argued that the lesson of Kosovo was that: "the rule book of international politics has been torn up. Interdependence - the fact of a crisis somewhere becoming a crisis everywhere - makes a mockery of traditional views of national interest' (Blair 2006c). In response to Kosovo, Robin Cook called for a 'new internationalism', transposing a term from the socialist tradition onto a narrative accepting of the neoliberal forces of globalisation (Cook 1999).

The same logics of regional risks becoming globalised, increasing need for intervention, and Britain's role as a leading power, were all evident in the UK's response to the dilemma of how to deal with the global phenomenon of Islamist terrorism. Although it was common for security policymakers to emphasise the extent to which $9 / 11$ represented a major change in the security environment, Blair argued that: 'At another level, it made sense of developments' he had 'seen growing in the world these past years' (Blair 2010: 345). In particular, he depicted Britain as embroiled in 'a battle that was ideological...about the force and consequence of globalisation' (Blair 2010: 346). In response to the growth in Islamist terrorism, Blair argued elsewhere that: 'we have to act, not react; we have to do so on the basis of prediction not certainty; and such action will often, usually indeed, be outside of our own territory' (Blair 2006c). In other words, actions in the name of British security would be based on the looser basis of probability and prediction rather than material evidence. To gain international support for them, Blair argued for: 'an agreed basis of principle, of values that are shared and fair. Common action only works when founded on common values' (Blair 2006c). 
From an interpretivist perspective, the agreed basis Blair evoked is perhaps as revealing by its omissions as by what it included. In conjuring up supposedly 'global values', largely derived from a liberal democratic tradition of 'liberty, democracy, tolerance, justice', it is striking that there is no mention of human rights in the entire speech, and only one mention of the rule of law, centred on events in Iraq. Neither are human rights mentioned at all in the second of his three valedictory speeches on foreign policy in 2006, specifically dedicated to outlining the basis of these 'global' values. To the fore then, in fact, was the neoliberal emphasis on free markets and democratic governance, rather than other possible aspects of this tradition like individual rights. Blair's characteristic framework for discussing security challenges was themed around a series of binary oppositions, such as the 'the age-old battle between progress and reaction', progressives versus conservatives, engagement versus isolation, modernity versus a 'pre-feudal' ideology, extremism versus 'the true voice of Islam', and the 'reactionary and regressive' in opposition to those who believe in democracy and liberty (Blair 2006a). In doing so, it is apparent that Blair offers a polarised, manichean world in which neoliberal economics and politics were privileged as 'progressive' and enlightened, with intervention in notionally sovereign states justified as part of a civilizing process.

On the face of it, the Conservative-Liberal coalition government from 2010 has questioned this appraisal of British security, certainly as far as New Labour's commitment of troops around the globe is concerned. David Cameron asserted in his first Mansion House speech in November 2010 that New Labour had, militarily, 'made too many commitments without the resources to back them up' (Cameron 2010). Although he did commit British forces to action in Libya five months later, it is notable that he emphasised: 'It is not about choosing the Government of Libya; that is an issue for the Libyan people' (Cameron 2011). In light of controversy over the legal basis to the 2003 
Iraq war, Cameron introduced three key criteria to intervention: 'demonstrable need, regional support, and a clear legal basis' (Cameron 2011). The last two of these were absent from Blair's six criteria for action set out in his Chicago speech and suggested a greater emphasis on multilateralism and international law (see Daddow and Schnapper 2013). Yet, in security terms, it is arguable that Cameron was still committing Britain to a 'war of choice' rather than necessity. Just as Blair had attempted to link Kosovo to Europe's regional security, so Cameron also defended action on Libya in the same manner: 'We simply cannot have a situation where a failed pariah state festers on Europe's southern border' (Cameron 2011). The assumption that security threats required a response even if they were distant, and that Britain should play a leading role in international action, were accepted unchallenged.

In short, the tradition of neoliberalism at the 'end of history' has been a potent force in British security thinking in the post-Cold War era. Underlying beliefs about globalisation, interconnectedness, and the universalising pressure for 'global values' has encouraged policymakers to see indirect threats as of major importance. In the process, Britain has been able to continue, and reinforce, the performance of its self-identity as a global leader via the use of military force. As a result, it has largely avoided making difficult choices about demilitarisation and has made little effort to radically redesign its security forces to confront non-military threats from transnational crime, the environment, health risks, and insecurities in the structure of the neoliberal economic system.

\section{CONCLUSION}


This chapter explored the traditions and dilemmas that have informed British security thought and practice since 1945. Going back to the end of the Second World War we interpreted the composition of the underlying traditions that have been brought to bear in this realm, whilst illustrating how a series of dilemmas compelled policy elites, incrementally and reluctantly, to confront new knowledge and reconfigure their web of beliefs about how to secure and advance British security interests as a result. In the period 1945-73 policy-makers cleaved to a Realist understanding of security as an extension of foreign policy, all framed by the Churchillian tradition of seeing Britain as a 'great' global power positioned at the intersection of global diplomacy and military might. This was security achieved via the influence that came from Britain being a founder member of the P-5 of the UN and the NATO alliance, glossed rhetorically with enthusiastic talk of the vitality of the Anglo-American 'special relationship'. . The Commonwealth remnants of Empire helped Britain support its global troop commitments physically in the form of forward military bases and access to naval ports, and in the initial post-war years by providing a relatively secure economic foundation. Europe was the poor relation of the three circles; British decision-makers in both main political parties were interested in Europe but preferred not to be too closely associated with nascent moves to integration as they developed through the 1950s.

The end of the Cold War saw the 'Western' understanding of the 'end of history' give real impetus to the idea that the 'Cold War was 'won', with the neoliberal economic model itself becoming part of the security narrative British policymakers defended and promoted. The tradition of claiming 'great' power pretensions for Britain never left the rhetoric, as we have seen through our study of Blair and Cameron's speeches and writings on security. Policymaking elites bolted their new knowledge about the impact of globalisation onto the Churchill tradition. Significantly, they did not wish or seek to 
overturn it, so much as rework Churchill for the modern era, in light of their understanding of 'new' realities after 1989. Their belief in the power of the 'special relationship' to advance British security continued to go hand in hand with a suspicion of the European dimension of British security (Liddle 2005), even as Britain was playing a leading role in redesigning and modernising European defence to cope with the challenges of ethnic cleansing and humanitarian crises in and around Europe's borders. As demands grow for a referendum on Britain's membership of the EU, the sense we have is that Britain may be about to enter a new phase of introspection into its security interests which may, should withdrawal from the EU be sought, lead to another upheaval to rival both 1973 and 1989.

\section{REFERENCES}

Allen, D. (2011) 'New Labour and Nuclear Weapons' in O. Daddow and J. Gaskarth, British Foreign Policy: The New Labour Years; Basingstoke: Palgrave, 139-153.

Ashton, N.J. (2005) 'Harold Macmillan and the "Golden Days" of Anglo-American Relations Revisited, 1957-63', Diplomatic History, 29(4): 691-723.

Blair, T. (1998) 'Statement announcing end of air strikes’ 20 December. Online. Available HTTP: http://news.bbc.co.uk/1/hi/events/crisis_in the_gulf/texts_and transcripts/239134.stm (accessed 12 February 2013).

Blair, T. (1999a) 'Statement on Kosovo to the House of Commons' 23 March. Online. Available HTTP: http://www.guardian.co.uk/world/1999/mar/23/balkans.tonyblair (accessed 12 February 2013).

Blair, T. (1999b) 'Doctrine of the International Community', Speech in Chicago, 23 April. 
Online. Available HTTP: http://www.pbs.org/newshour/bb/international/janjune99/blair_doctrine4-23.html (accessed 12 February 2013).

Blair, T. (2006a) 'Clash about Civilisations', Speech in London, 21 March.

Blair, T. (2006b) 'Global alliance for global values', Speech in Canberra, Australia, 27 March.

Blair, T. (2006c) 'Reform of Global Institutions' Speech in Washington, D.C., USA, 26 May.

Blair, T. (2010) A Journey, London: Hutchinson.

Bonner, D. (2007) Executive Measures, Terrorism and National Security: Have the Rules of the Game Changed?, Aldershot: Ashgate.

Bratberg, Ø. (2011) 'Ideas, Tradition and Norm Entrepreneurs: Retracing Guiding Principles of Foreign Policy in Blair and Chirac's Speeches on Iraq', Review of International Studies, 37(1): 327-48.

Brown, S. (2013), ‘An island once again', The European, 10 January. Online. Available HTTP: http://www.theeuropean-magazine.com/935-brown-stuart/937-a-referendum-on-europe (accessed 12 February 2013).

Cameron, D. (2010) 'Speech to Lord Mayor's Banquet' 15 November. Online. Available HTTP: http://www.number10.gov.uk/news/speech-to-lord-mayors-banquet/ (accessed 12 February 2013).

Cameron, D. (2011) 'UN Security Council Resolution (Libya)’ 18 March, Col 616. Online. Available HTTP: http://www.publications.parliament.uk/pa/cm201011/cmhansrd/cm110318/debtext

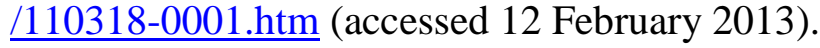

Chalmers, M. (2011) 'Keeping Our Powder Dry?', The RUSI Journal, 156,1, 20-28. Churchill, W. (1948) speech to Conservative Party Conference, official proceedings of Conservative Party Conference, Bodleian Library Special CollectiOns, shelf mark NUA 2/1/56, 149-56. 
Clancy, R. (2012) 'Britain is in an economic 'war'” says Cameron, Daily Telegraph, 19 November. Online. Available HTTP: http://www.telegraph.co.uk/finance/economics/9688715/Britain-is-in-aneconomic-war-says-Cameron.html (accessed 12 February 2013).

Clarke, M. (1988) 'The Policy-making Process', in M. Smith, S. Smith and B. White (eds) British Foreign Policy: Tradition, Change and Transformation, London: Hyman, pp.71-95.

Coles, J. (2000) 'Making Foreign Policy Matter’, The RUSI Journal, 145(3): 1-7.

Cook, R. (1999) 'Speech to the Labour Party Conference', 28 September. Online. Available HTTP: http://news.bbc.co.uk/1/hi/uk_politics/459926.stm (accessed 13 February 2013).

Cook, R. (2000) 'Foreign Policy and National Interest' Speech at Chatham House, 28 January.

Curtis, M. (2004) 'Britain’s Real Foreign Policy and the Failure of British Academia', International Relations, 18(3): 275-87.

Daddow, O.J. (2003) 'Introduction: The Historiography of Wilson's Attempt to Take Britain into the EEC', in O.J. Daddow (ed.) Harold Wilson and European Integration: Britain's Second Application to Join the EEC, London: Frank Cass, pp.1-36.

Daddow, O. (2011) New Labour and the European Union: Blair and Brown's Logic of History, Manchester: Manchester University Press.

Daddow, O. and Gaskarth, J. (2011) ‘Introduction: Blair, Brown and New Labour’s Foreign Policy, 1997-2010', in O. Daddow and J. Gaskarth (eds) British Foreign Policy: The New Labour Years, Basingstoke: Palgrave Macmillan, pp.1-27.

Daddow, O. and Schnapper, P. (2013) 'Liberal Intervention in the Foreign Policy Thinking of Tony Blair and David Cameron', Cambridge Review of International Affairs (forthcoming).

Deighton, A. (2005) Working Paper, 'The Foreign Policy of British Prime Minister Tony Blair: Radical or Retrograde?', Centre for British Studies, Humboldt University Berlin, 11 
July, available at http://www.gbz.hu-berlin.de/publications/working-papers/, accessed 16 August 2012.

Donohue, L. (2008) The Cost of Counterterrorism: Power, Politics, and Liberty, Cambridge: Cambridge University Press.

Farrell, T. (2008) 'The dynamics of British military transformation' International Affairs, 84(4): 777-807.

Finnemore, M. and Sikkink, K. (2001) 'The Constructivist Research Program in International Relations and Comparative Politics', Annual Review of Political Science, 4(1): 391-416.

Freedman, L. (1976) 'Logic, Politics and Foreign Policy Process: A Critique of the Bureaucratic Politics Model', International Affairs, 52(3): 434-49.

Garden, T. (2000) 'The United Kingdom \& the Kosovo Operation' Presentation to 3Cdo RM Kosovo briefing day - 24 February. Online. Available HTTP: http://www.tgarden.demon.co.uk/writings/articles/2000/000224rmkos.html (accessed 12 February 2013).

Gaskarth, J. (2006) 'Discourses and Ethics: The Social Construction of British Foreign Policy' Foreign Policy Analysis (October), 2,(4), 325-341.

Gaskarth, J. (2013) British Foreign Policy; Cambridge: Polity Press.

Gautam, P.K. (2009) 'Ways of Warfare and Strategic Culture', Defense and Security Analysis, 25(4): 413-23.

Hewitt, S. (2007) British War on Terror: Terrorism and Counter-terrorism on the Home Front since 9/11, Continuum.

Hill, C. (2010) 'Tough Choices', The World Today, April, 11-14.

Hobson, C. (2011) 'Towards a Critical Theory of Democratic Peace', Review of International Studies, 37(4): 1903-1922.

Horne, A. (1991) Macmillan, 1957-1986: Volume 2 of the Official Biography, London: 
Papermac.

Hurd, Lord (1998) 'British Foreign Policy in the Aftermath of the Cold War', The RUSI Journal, 143(6): 6-10.

Kavanagh, D. and Morris, P. (1994) Consensus Politics from Attlee to Major (2 ${ }^{\text {nd }}$ edn), Oxford: Blackwell.

Kennedy, P. (1985) The Realities behind Diplomacy: Background Influences on British External Policy 1865-1980, London: Fontana.

Kent, J. and Young, J.W. (1989) 'British Policy Overseas, the Third Force and the Origins of NATO - in Search of a New Perspective', in B. Heuser and R. O’Neill (eds) Securing Peace in Europe, 1945-62: Thoughts for the Post-Cold War Era, Basingstoke: Macmillan, pp.41-61.

Keohane, R.O. (1986) 'Realism, Neorealism and the Study of World Politics', in R.O. Keohane (ed.) Neorealism and its Critics, New York: Columbia University Press, pp. 1-26.

King, A. (2008) 'The Special Air Service and the Concentration of Military Power', Armed Forces and Society, 35(4): 646-66.

King, A. (2011) 'Having brigades will never deliver the same punch as a division' Parliamentary Brief Online, 27 October. Online. Available HTTP: http://www.parliamentarybrief.com/2011/10/having-brigades-will-never-deliver-the-

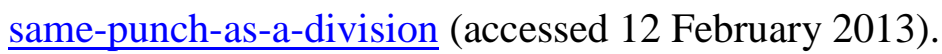

Liddle, R. (2005) The New Case for Europe. London: Fabian Society.

Mearsheimer, J.J. (2001) The Tragedy of Great Power Politics, London: W.W.Norton and Company.

Meyer, C. (2010) Getting Our Way. 500 Years of Adventure and Intrigue: The Inside Story of British Diplomacy, London: Phoenix.

Miskimmon, A. (2004) 'Continuity in the Face of Upheaval: British Strategic Culture and the Impact of the Blair Government', European Security, 13(3): 273-299. 
MOD (Ministry of Defence), (1998) Strategic Defence Review. London: The Stationery Office.

Portillo, M. (1995) 'Speech to Conservative Party Conference', Online. Available HTTP: http://www.youtube.com/watch?v=ESxaGRjXhCk (accessed 12 February 2013).

Rynning, S. (2003) 'The European Union: Towards a Strategic Culture?' Security Dialogue, 34(4): 479-496.

Searle, J.R. (1995) The Construction of Social Reality, London: Penguin.

Shlaim, A. (1977) 'The Foreign Secretary and the Making of Foreign Policy', in A. Shlaim, P. Jones and Sainsbury, British Foreign Secretaries since 1945, London: David \& Charles, pp.13-26.

Theakston, K. (2004) 'The Changing Role of the Foreign Secretary', in K. Theakston (ed.) British Foreign Secretaries since 1974, London: Routledge, pp.1-46.

Toomey, J. (2003) 'Ireland and Britain's Second Application to Join the EEC', in Oliver J. Daddow (ed), Harold Wilson and European Integration: Britain's Second Application to Join the EEC, London: Frank Cass, pp.227-42.

Toye, R. (2008) 'The Churchill Syndrome: Reputational Entrepreneurship and the Rhetoric of Foreign Policy since 1945', British Journal of Politics and International Relations,10(3): 364-78.

Váška, J. (2009) 'Between Tradition and Modernity: Britain’s Foreign Policy in the Second Half of the 1960s', Acta Univeritatis Carolinae Studia Territorialia IV: 119-48.

Uz Zaman, R. (2009) 'Strategic Culture: A “Cultural” Understanding of War', Coparative Strategy, 28(1): 68-88.

Vickers, R. (2011) The Labour Party and the World, Volume 2: Labour's Foreign Policy since 1951, Manchester: Manchester University Press.

Wallace, W. (1992) 'British Foreign Policy After the Cold War', International Affairs, 68(3): 423-442. 
Wallace, W. and Phillips, C. (2009) 'Reassessing the special relationship' International Affairs, 85(2), 263-284.

Waltz, K.N. (2010) Theory of International Politics, Long Grove, Ill.: Waveland Press.

Wendt, A. (1995) ‘Constructing International Politics', International Security 20(1): 71-81. 